\title{
Bone morphogenetic protein 7 is associated with the nodal invasion of colon cancer
}

\author{
TIANQI ZHANG ${ }^{1}$, JINING FU ${ }^{2}$, YUETING LI ${ }^{3}$, YAOHUI WANG ${ }^{4}$, LONG ZHANG $^{2}$ and YING LIU ${ }^{5}$ \\ ${ }^{1}$ Teaching and Research Department of Biology, The First Senior Middle School, Siping, Jilin 136001; ${ }^{2}$ Department of \\ General Surgery, Siping Hospital of China Medical University, Siping, Jilin 136000; ${ }^{3}$ Department of General Surgery, \\ Beijing Hospital of Traditional Chinese and Western Medicine, Beijing 100088; Departments of ${ }^{4}$ Oncology, and \\ ${ }^{5}$ Science and Technology, Siping Hospital of China Medical University, Siping, Jilin 136000, P.R. China
}

Received October 28, 2015; Accepted January 13, 2016

DOI: $10.3892 / \mathrm{ol} .2016 .4102$

\begin{abstract}
Environmental and genetic factors interact in the process and treatment of colon cancer, although the underlying mechanisms remain elusive. The aim of the study was to examine the role of whether bone morphogenetic protein 7 (BMP7) is involved in the progression of colon cancer under local intratumoral infiltration lymphocytes. A total of 46 cases of pathologically confirmed specimens were obtained from patients with nodal invasion of colon cancer. The patients were subdivided into three groups based on the nodal invasion stages (N0, N1 and N2). Eleven cases without nodal invasion of colon cancer served as the control group (N0). The phenotype of $\mathrm{CD}_{4} 5^{+}, \mathrm{CD}^{+}, \mathrm{CD}^{+}, \mathrm{CD} 25^{+}$and $\mathrm{CD}^{+} 6^{+}$cells and the expression of BMP7 were confirmed by immunofluorescence. The association between BMP7 expression and $\mathrm{CD} 45^{+} / \mathrm{CD} 4^{+} \mathrm{CD} 25^{+} / \mathrm{CD}^{+}$cells infiltration was analyzed. The density of $\mathrm{CD} 4^{+} \mathrm{CD} 25^{+} \mathrm{T}$ cells within the tumor was associated with nodal invasion in patients with colon cancer. More importantly, the expression of BMP7 was observed in the majority of the cancer tissues. The co-expression pattern of BMP7 in colon cancer cells and intratumor $\mathrm{CD} 4^{+} \mathrm{CD} 25^{+} \mathrm{T}$ cells was associated with nodal invasion of colon cancer. In conclusion, the results have shown that the co-expression of BMP7 is inversely associated with the infiltration of $\mathrm{CD} 4{ }^{+} \mathrm{CD} 25^{+} \mathrm{T}$ cells of colon cancer. The results suggest the combination of adaptive immunotherapy and biological drugs impact the treatment strategy for colon cancer in distinct clinical settings.
\end{abstract}

\section{Introduction}

Inflammatory cells are present in the tumor microenvironment of most cancers and have been reported to affect tumor progres-

Correspondence to: Professor Ying Liu, Department of Science and Technology, Siping Hospital of China Medical University, 89 Nanyingbin Road, Siping, Jilin 136000, P.R. China E-mail:1y364129@163.com

Key words: bone morphogenetic protein $7, \mathrm{CD} 4^{+} \mathrm{CD} 25^{+} \mathrm{T}$ cells, colon cancer, nodal invasion sion (1-3). The long-term survival of patients with colon cancer is dependent on the pathological stage as well as the complex interactions between tumor- and patient-associated factors. In particular, systemic and local host inflammatory responses are important determinants of cancer outcome. In contrast to the systemic response, local infiltration of inflammatory cells in the tumor microenvironment is associated with improved survival in patients with colon cancer. Tumor-infiltrating $\mathrm{T}$ cells may be an indicator of host immune response to tumor and an attractive target for immunotherapy (4-7). However, the specific role of individual leukocytic infiltrates in individual tumors remains to be elucidated. This diversity of immunologic response to malignancies renders the targeting of the immune system as part of anticancer therapies a challenge.

Treatment of advanced colon cancer has improved over the past 15 years. The combination of chemotherapy and biological drugs, such as anti-epidermal growth factor receptor (EGFR) or anti-vascular endothelial growth factor antibodies, as well as the sequencing of different active drugs as the disease progresses, can significantly improve outcomes $(8,9)$. In particular, treatment with monoclonal antibodies (cetuximab or panitumumab) against the extracellular domain of the receptor has become a major therapeutic strategy in the treatment of metastatic colorectal cancer. However, the responses to EGFR-targeted antibodies are relatively low, with improvements in survival usually lasting only several months, and efficacy limited to certain patient subtypes (10). Nevertheless, despite these advances, the optimal treatment for patients with advanced colon cancer in clinical practice is not yet defined.

Overexpression of bone morphogenetic protein 7 (BMP7) promotes gene amplification and mutation consequence in cell proliferation, survival, invasion, metastasis, and tumor-induced neoangiogenesis (11-14). Thus targeting BMP7 constitutes an effective therapy in colon cancer. In the present study, the BMP7 expression in surgical specimens of colon cancer was examined to assess the association between this molecule and local immune response. The examination of individual cell types cannot predict outcomes, but it does suggest a prominent role at the level of nodal involvement and lymphatic invasion in these patients. Thus, the results support that the combination of adaptive immunotherapy and biological drugs impact the treatment strategy for colon cancer in distinct clinical settings. 
Table I. Pathological characteristics of colon cancer patients.

\begin{tabular}{|c|c|c|c|}
\hline Characteristics & No & N1 & $\mathrm{N} 2$ \\
\hline Median age (range), years & $62.36(51-72)$ & $61.19(53-69)$ & $60.72(50-71)$ \\
\hline \multicolumn{4}{|l|}{ Gender, no. (\%) } \\
\hline Female & $5(37.5)$ & $9(46.9)$ & $6(47.6)$ \\
\hline Male & $6(62.5)$ & $11(53.1)$ & $9(52.4)$ \\
\hline \multicolumn{4}{|l|}{$\mathrm{T}$ stage primary tumor, no. (\%) } \\
\hline T0 & 0 & 0 & 0 \\
\hline $\mathrm{T} 1$ & 0 & 0 & 0 \\
\hline $\mathrm{T} 2$ & 2 & 0 & 0 \\
\hline $\mathrm{T} 3$ & 9 & 20 & 15 \\
\hline $\mathrm{T} 4$ & 0 & 0 & 0 \\
\hline \multicolumn{4}{|l|}{$\mathrm{N}$ stage primary tumor, no. $(\%)$} \\
\hline Node-negative & $11(100.0)$ & 0 & 0 \\
\hline Node-positive & 0 & $20(100.0)$ & $15(100.0)$ \\
\hline N1 & 0 & $20(100.0)$ & 0 \\
\hline $\mathrm{N} 2$ & 0 & 0 & $15(100.0)$ \\
\hline \multicolumn{4}{|l|}{ M stage primary tumor, no. (\%) } \\
\hline M0 & $11(100.0)$ & $14(50.0)$ & $11(100.0)$ \\
\hline M1 & 0 & $6(50.0)$ & 4 \\
\hline Largest median diameter, $\mathrm{cm}$ (range) & $3.29(2.11-7.36)$ & $5.56(2.09-8.73)$ & $6.67(2.13-9.84)$ \\
\hline
\end{tabular}

\section{Materials and methods}

Clinical samples. Paraffin-embedded specimens of patients with colorectal cancer (stages I-III) were retrieved retrospectively from 46 patients who underwent surgery at the Department of Surgery, Siping Hospital of China Medical University (Siping China), between January 2005 and December 2014. The present study was approved by the Research Ethics Committee at Siping Hospital of China Medical University.

The patients were divided into 3 groups as per their nodal metastasis grade (N0, N1, or N2). The first group comprised 11 patients (N0), the second group 20 patients (N1), and the third group 15 patients (N2). The exclusion criteria for the study were: i) Clinical evidence of active infection; ii) the presence of a chronic inflammatory condition; and iii) preoperative chemoradiotherapy. The tumors were staged according to the fifth edition of the tumor, node and metastasis classification (15). Additional pathological data were obtained from reports issued at the time of resection. The clinicopathological characteristics of patients are shown in Table I.

Immunofluorescence of paraffin-embedded tissue sections and evaluation of staining. Paraffin-embedded sections $(4 \mu \mathrm{m})$ were obtained to assess lymphocyte markers, including CD4 (rabbit, polyclonal, IgG, catalog no: ABIN671376 at a dilution of 1:1000), CD8 (rabbit, polyclonal, IgG, catalog no: ab85792 at a dilution of 1:1000), CD25 (mouse, monoclonal, catalog no: ABIN320392 at a dilution of 1:1000), CD45 (rabbit, polyclonal, IgG, catalog no: ab17553 at a dilution of 1:1000) and CD56 (mouse, monoclonal, catalog no: ABIN2658999 at a dilution of 1:1000). The primary antibodies were purchased from BD Biosciences (Wuhan, China). To detect CD4 and CD25, a general Treg cell antigen was used. CD45 was used as a common leukocyte antigen. CD8 was used as a cytotoxic T lymphocyte (CTL) marker. CD45 was used as a leukocyte common antigen and CD56 was used as an NK cell marker. BMP7 immunoreactivities were detected in the nucleus, and the data were evaluated as a labeling index (LI), as previously described (16). Fluorescent staining with anti-mouse and anti-rabbit Ig secondary antibodies [anti-rabbit IgG (H+L)-FITC: 211-095-109, Jackson ImmunoResearch, Düsseldorf, Germany] conjugated with Alexa dyes 488 and 568 (Invitrogen Life) conjugated with Alexa dyes 488 and 568 (Invitrogen Life Technologies, Paisley, UK) was used for double staining (CD4 and CD25; CD8 and CD56). Nuclear counterstaining in this case was performed with DAPI (Roche, Mannheim, Germany). Counting was performed under a microscope (Olympus, BX51TF, Tokyo, Japan) at a magnification of x400. Stained immune cells were assessed without knowledge of the clinical parameters of each patient. The positive cells were evaluated in the nuclei of $>1,000$ tumor cells for each case, and LI was calculated as the percentage of each type of positive cell per 1,000 tumor cells counted at random in each section. The cells in each sample were examined blindly by three independent expert observers.

Statistical analysis. Data are shown as mean \pm standard deviation. Cross-tabulations variables were analyzed using Fisher's exact test. Statistical analyses were performed using SPSS software, version 19.0 (IBM SPSS, Chicago, IL, USA). $\mathrm{P}<0.05$ was considered to indicate a statistically significant difference. 
Table II. Associatoin between individual T lymphocyte and the nodal invasion of colon cancer. ${ }^{\mathrm{a}}$

Percentage of individual T lymphocyte of colon cancer

\begin{tabular}{lllccc}
\cline { 2 - 5 } Nodal invasion group & \multicolumn{1}{c}{$\mathrm{CD}^{2}$} & \multicolumn{1}{c}{$\mathrm{CD}^{+}$} & $\mathrm{CD}^{+} \mathrm{CD} 25^{+}$ & $\mathrm{CD}^{+}$ & CD56 $^{+}$ \\
\hline N0 & $46.32 \pm 6.08$ & $14.63 \pm 3.47$ & $8.11 \pm 3.26$ & $6.23 \pm 3.13$ & $4.41 \pm 1.13$ \\
N1 & $31.61 \pm 4.65^{\mathrm{a}, \mathrm{b}}$ & $21.19 \pm 6.12^{\mathrm{a}}$ & $15.42 \pm 5.09^{\mathrm{a}}$ & $2.14 \pm 2.08^{\mathrm{a}}$ & $1.98 \pm 0.69^{\mathrm{a}}$ \\
N2 & $16.74 \pm 3.37^{\mathrm{b}, \mathrm{c}}$ & $28.63 \pm 11.35^{\mathrm{c}}$ & $21.37 \pm 11.33^{\mathrm{c}}$ & $0.21 \pm 0.36^{\mathrm{c}}$ & $0.19 \pm 1.01^{\mathrm{b}}$
\end{tabular}

In comparison to $\mathrm{N} 1$, parameters in $\mathrm{N} 1$ and $\mathrm{N} 2$ showed ${ }^{\mathrm{a}} \mathrm{P}<0.05$; ${ }^{\mathrm{b}} \mathrm{P}<0.01$. In comparison to $\mathrm{N} 1$, parameters in $\mathrm{N} 2,{ }^{\mathrm{b}} \mathrm{P}<0.05 ;{ }^{\mathrm{c}} \mathrm{P}<0.01$. Data are shown as mean \pm standard deviation.
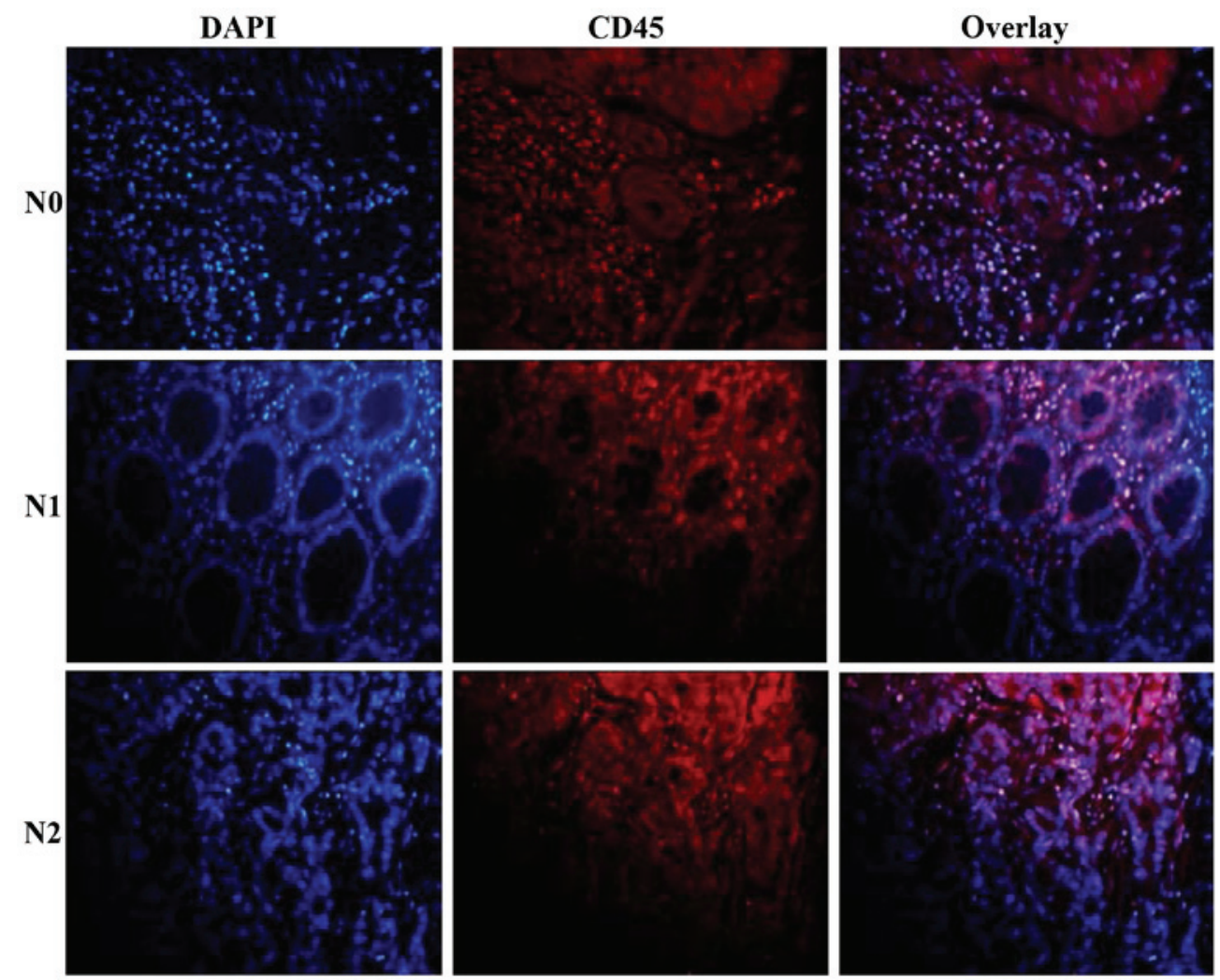

Figure 1. Expression of $\mathrm{CD}_{4} 5^{+}$lymphocytes in colon cancer tissue. $\mathrm{CD} 45^{+}$lymphocytes were observed in the N0, N1 and N2 nodal invasion groups.

\section{Results}

Evaluation of $\mathrm{CD}^{4} 5^{+}$cells at the site of colon cancer tissue. Gross examination revealed massive infiltration of $\mathrm{CD}^{4} 5^{+}$cells confined to nodal invasion (Fig. 1). Different patterns of immune cell accumulations were observed among the patients which potentially coexisted within the same specimen in colon cancer tissue as single cells and diffused cell aggregates (Table II, Fig. 1). CD $45^{+}$cells were ranged at a percentage of $46.32,31.61$ and $16.74 \%$ in the N0, N1 and N2 nodal invasion groups, respectively (Table II, Fig. 1).

Patient-specific extent and organization pattern of $C D 4^{+} C D 25^{+}$T lymphocytes in tumor tissue. To characterize the T-cell lineages in tumor tissue, the tissue specimens were analyzed for $\mathrm{CD} 4{ }^{+} \mathrm{CD} 25^{+}$cells. The major propor- tion of cells within the large lymphocyte aggregates was $\mathrm{CD} 4{ }^{+} \mathrm{CD} 25^{+} \mathrm{T}$ cells in the $\mathrm{N} 2$ nodal invasion group. Quantitative evaluations of the three groups revealed the presence of $\mathrm{CD} 4{ }^{+} \mathrm{CD} 25^{+} \mathrm{T}$ cells in tumor tissue, ranging from $8.11,15.42$ to $21.37 \%$ in the N0, N1 and N2 nodal invasion groups (Table II, Fig. 2).

$C D 8^{+} T$ lymphocytes assemble within the metastatic colon cancer. An important observation of the current study was the presence of $\mathrm{CD}^{+} \mathrm{T}$ lymphocytes at the site of the tumor tissue. $\mathrm{CD}^{+} \mathrm{T}$ lymphocytes were detected in all of the patients in the NO nodal invasion group. A comparison of the three groups regarding $\mathrm{CD}^{+} \mathrm{T}$ lymphocytes in the tumor tissue revealed statistically significant differences (Fig. 3, Table II), whereas no $\mathrm{CD}^{+} \mathrm{T}$ lymphocytes were typically present in the $\mathrm{N} 2$ nodal invasion group (Fig. 3, Table II). 

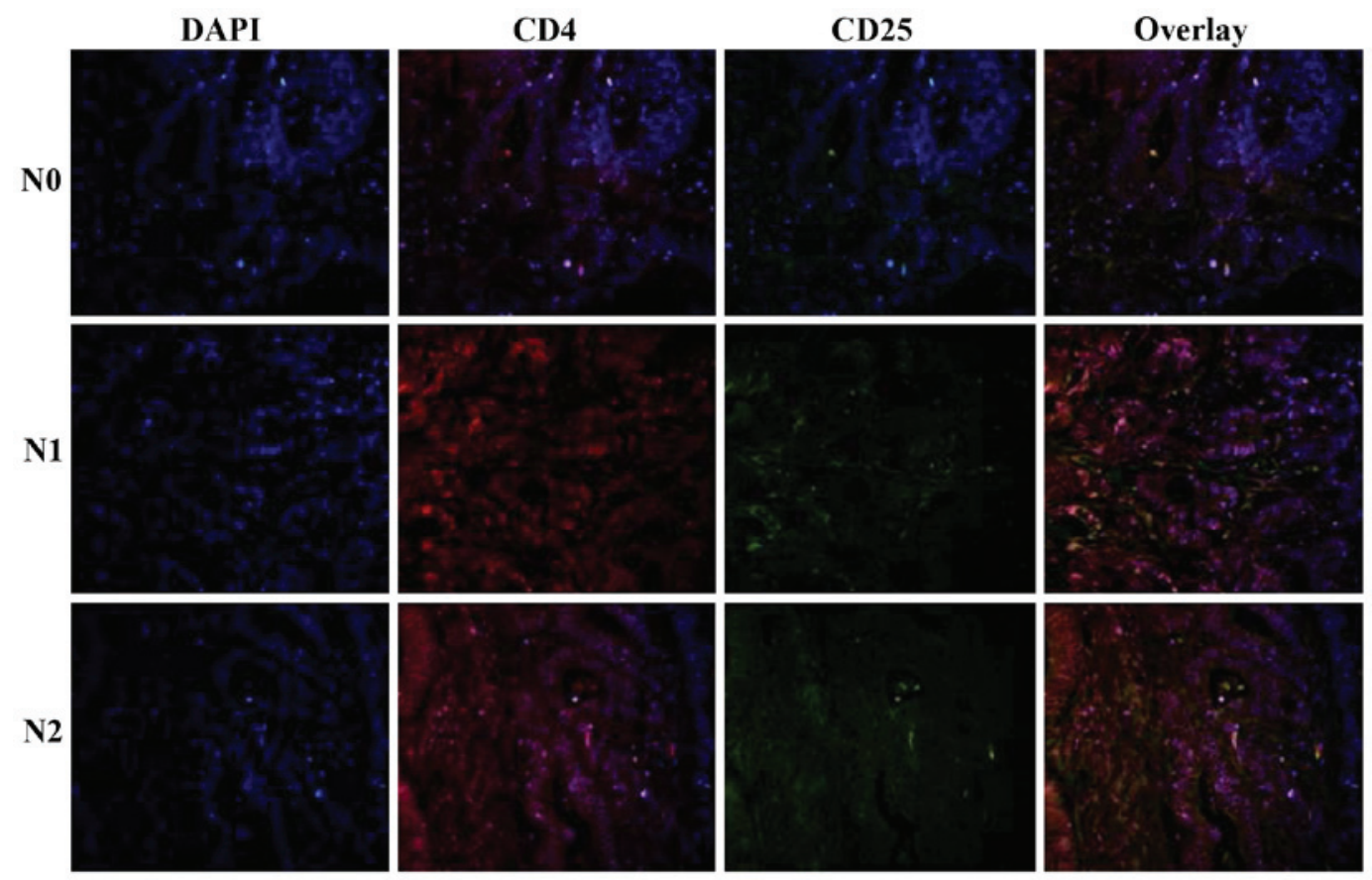

Figure 2. Expression of $\mathrm{CD} 4^{+} \mathrm{CD} 25^{+} \mathrm{T}$ cells in colon cancer tissue

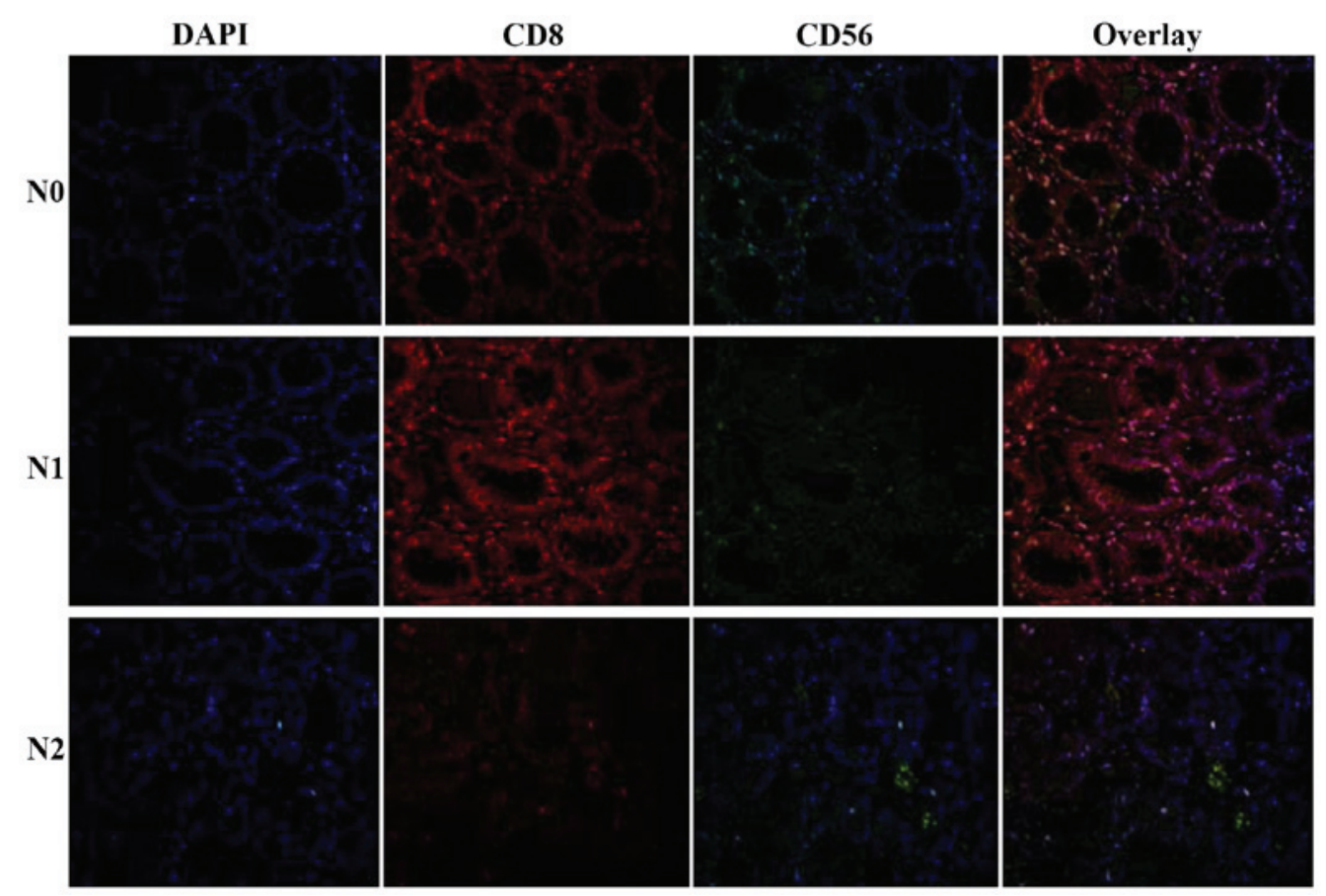

Figure 3. Expression of $\mathrm{CD} 8^{+} \mathrm{CD} 56^{+} \mathrm{T}$ cells in colon cancer tissue. Compared to other groups, no $\mathrm{CD} 8^{+} \mathrm{T}$ lymphocytes were observed in the $\mathrm{N} 2$ nodal invasion group and few $\mathrm{CD}_{5} 6^{+} \mathrm{T}$ cells were observed in the N0 nodal invasion group.

To characterize the role of NK cells in tumor tissue, tissue sections were stained with anti-CD56 to define the fully active, intra-tumoral NK cells. Only trace numbers of CD56 ${ }^{+}$cells were observed in the N0 nodal invasion group (Fig. 3, Table II).

Expression of BMP7 in colon cancer. The expression patterns and cellular localization of BMP7 in 46 colon cancer tissues of three differentiation levels were assessed by immunofluorescence analysis. As shown in Table III and Fig. 4, BMP7 immunoreactivity was predominantly localized in the nuclei of CRC cells, whereas BMP7 was significantly higher in the poor nodal invasion group than in the negative nodal group $(\mathrm{P}<0.01)$ (Table III, Fig. 4).

\section{Discussion}

The clinical course of remission and relapse is commonly observed in patients undergoing therapy for colon cancer (17). 

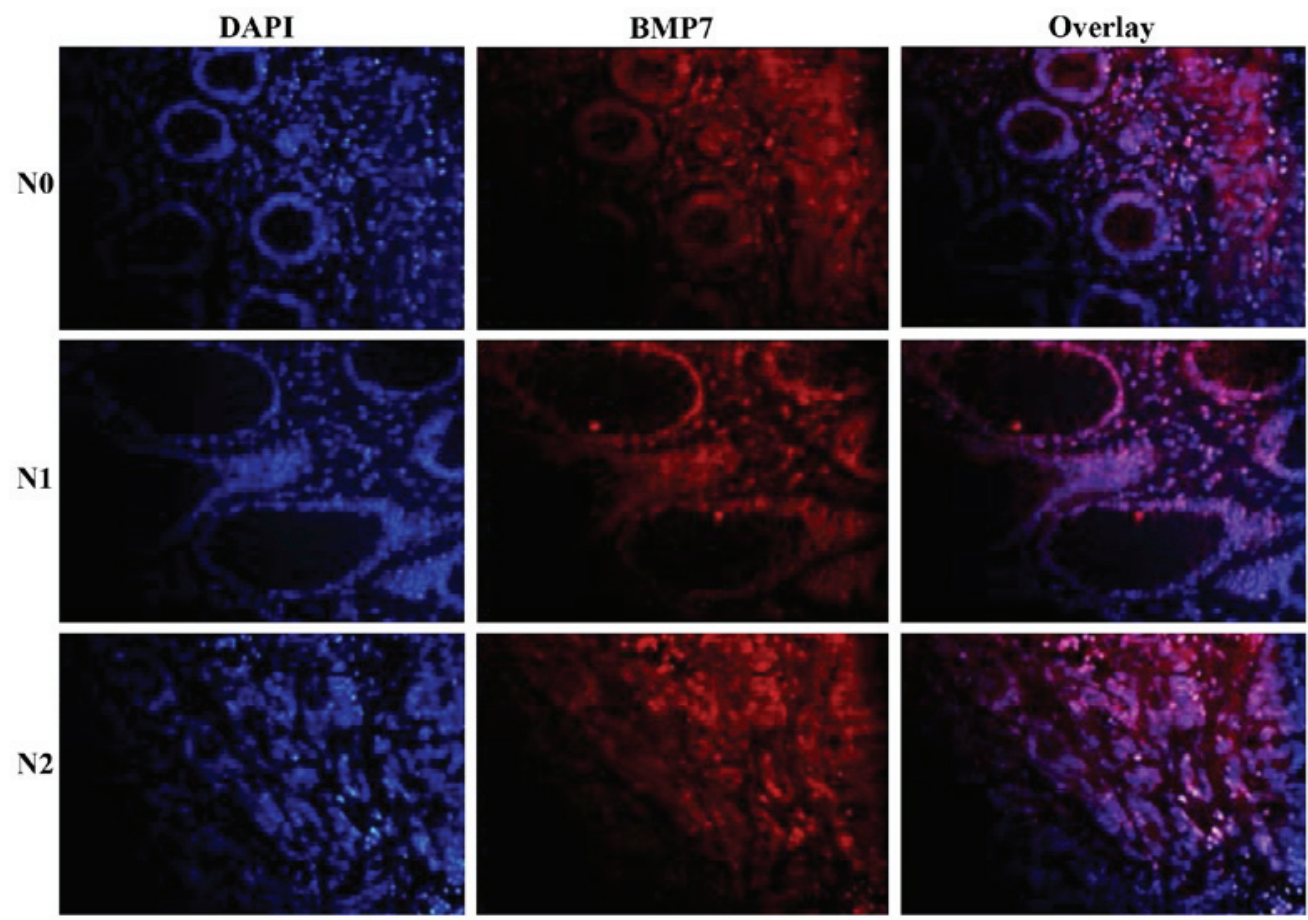

Figure 4. The expression of bone morphogenetic protein 7 (BMP7) in colon cancer tissue.

Table III. Analyze the expression of BMP7 intra-tumor of colon cancer.

\begin{tabular}{lccc}
\hline Expression & N0 & N1 & N2 \\
\hline BMP7 & $13.06 \pm 1.21$ & $28.32 \pm 5.64^{\mathrm{a}}$ & $40.73 \pm 8.35^{\mathrm{b}, \mathrm{c}}$ \\
\hline
\end{tabular}

In comparison to $\mathrm{N} 0$, parameters in $\mathrm{N} 1$ and $\mathrm{N} 2$ showed ${ }^{\mathrm{a}} \mathrm{P}<0.05$, ${ }^{\mathrm{b}} \mathrm{P}<0.01$. In comparison to the $\mathrm{N} 0$ and $\mathrm{N} 1$ group, parameters in $\mathrm{N} 2$ showed ${ }^{\mathrm{b}} \mathrm{P}<0.05,{ }^{\mathrm{c}} \mathrm{P}<0.01$. Data shown as mean \pm standard deviation.

In the present study, we detected the overexpression of BMP7 in colon cancer tissues in its advanced stage, in particular, its upregulation of BMP7 was closely associated with nodal metastasis. Thus, the combination of chemotherapy, radiation therapy, adaptive immunotherapy and biological drugs, such as anti-BMP7 antibodies for first-line treatment, can significantly improve outcomes.

The mechanisms by which a strong local adaptive immune response improves prognosis in patients with colon cancer remain to be elucidated. In the current study, we identified a highly significant and independent association of CD $45^{+}$lymphocyte infiltration in the preoperative biopsy with nodal invasion of colon cancer patients. The percentage of CD $45^{+}$lymphocytes decreased in the later stage of colon cancer tissue. Since the CD45 antigen was originally known as leukocyte common antigen (18), the findings strongly suggest that such patients mount a coordinated inflammatory response at a local level, mediated primarily by cells associated with adaptive immunity.

Immunotherapy was utilized for the treatment of colon cancers. To examine T-cell subsets, we evaluated the distribution of T lymphocytes with CD4, CD8 and CD25 phenotype and analyzed the association between different subsets of $\mathrm{T}$ lymphocytes and nodal metastasis in colon cancer tissue. For this study, CD4 and CD25 were selected as the regulatory markers for T cells, with CD8 being used as the effector CTLs. Using double immunoflourescent staining and confocal analysis, we confirmed that to a large extent the markers separate in the three different situations of nodal metastasis. We also evaluated $\mathrm{CD}^{+} 6^{+}$cells in colon cancer tissue, which is similar to $\mathrm{CD}^{+} \mathrm{T}$ cells, but decreased in the later stage of colon cancer. Of note, the mechanism of adaptive immunity limitation was of considerable interest and remains to be investigated.

Colon cancers resist certain therapies, such as chemotherapy and adaptive immunotherapy. To investigate the reason for this, the expression of BMP7 in colon cancer tissue was examined. BMP7 has been reported in a wide range of human cancers and has been associated with metastasis and poor prognosis $(14,19,20)$. In the current study, the expression of BMP7 was 13.4, 28.1 and 40.6\% in the N0, N1 and N2 stage, respectively. These findings suggest BMP7 overexpression tended to localize lymph node relapse. In contrast to cells associated with the adaptive immune response, an abundance of $\mathrm{CD} 4{ }^{+} \mathrm{CD} 25^{+} \mathrm{T}$ cells was associated with the abundance of BMP7 expression. These results suggest a protective host response, i.e., the collective effect of BMP7 expression and $\mathrm{CD} 4{ }^{+} \mathrm{CD} 25^{+} \mathrm{T}$-cell infiltration in the tumor may favor tumor growth and dissemination. Thus, our results suggest monoclonal antibodies may be used under immune contexture.

The study has some limitations. The identification and classification of individual T-cell types should be investigated. Additionally, more patients should be examined for concrete evidence and restricting potential clinical application. The present study focused only on the intra-tumor tissue and did not assess the inflammatory cell invasive margin of the tumor, which is reported to constitute a critical interface 
between pro- and anti-tumor factors. Furthermore, examination of the prognostic value of intra-tumor inflammatory cells and tumor molecular features need to be verified.

In conclusion, our results have demonstrated the co-expression of $\mathrm{CD} 4{ }^{+} \mathrm{CD} 25^{+} \mathrm{T}$ cells and BMP7 in a considerable percentage of patients with nodal metastatic colon cancer. Overexpression of BMP7 is a potential predictor of nodal invasion, while the molecular marker for high-risk patients may be useful in individualizing patient therapy, such as anti-BMP7 antibodies for first-line treatment, can significantly improve outcomes. In particular, the results suggest the combination of adaptive immunotherapy and biological drugs impact the treatment strategy for colon cancer in distinct clinical settings.

\section{Acknowledgements}

This study received a grant from the Department of Science and Technology of Jilin Province (Jilin, China) (no. 201105100), and special funds for Innovation and Industrial Development of the Independent Core Area (Beiijng, China) (2014).

\section{References}

1. Mantovani A, Allavena P, Sica A and Balkwill F: Cancer-related inflammation. Nature 454: 436-444, 2008.

2. Porta C, Larghi P, Rimoldi M, Totaro MG, Allavena P, Mantovani A and Sica A: Cellular and molecular pathways linking inflammation and cancer. Immunobiology 214: 761-777, 2009.

3. Solinas G, Marchesi F, Garlanda C, Mantovani A and Allavena P: Inflammation-mediated promotion of invasion and metastasis. Cancer Metastasis Rev 29: 243-248, 2010.

4. Zou W: Regulatory T cells, tumour immunity and immunotherapy. Nat Rev Immunol 6: 295-307, 2006.

5. Speetjens FM, Lauwen MM, Franken KL, Janssen-van Rhijn CM, van Duikeren S, Bres SA, van de Velde CJ, Melief CJ, Kuppen PJ, van der Burg SH, et al: Prediction of the immunogenic potential of frameshift-mutated antigens in microsatellite instable cancer. Int J Cancer 123: 838-845, 2008.

6. Curiel TJ: Tregs and rethinking cancer immunotherapy. J Clin Invest 117: 1167-1174, 2007.

7. Disis ML, Bernhard H and Jaffee EM: Use of tumour-responsive T cells as cancer treatment. Lancet 373: 673-683, 2009.

8. Schmoll HJ, Van Cutsem E, Stein A, Valentini V, Glimelius B, Haustermans K, Nordlinger B, van de Velde CJ, Balmana J, Regula J, et al: ESMO Consensus Guidelines for management of patients with colon and rectal cancer. a personalized approach to clinical decision making. Ann Oncol 23: 2479-2516, 2012.
9. Adam R, De Gramont A, Figueras J, Guthrie A, Kokudo N, Kunstlinger F, Loyer E, Poston G, Rougier P, Rubbia-Brandt L, et al; Jean-Nicolas Vauthey of the EGOSLIM (Expert Group on OncoSurgery management of LIver Metastases) group: The oncosurgery approach to managing liver metastases from colorectal cancer: a multidisciplinary international consensus. Oncologist 17: 1225-1239, 2012.

10. Siena S, Sartore-Bianchi A, Di Nicolantonio F, Balfour J and Bardelli A: Biomarkers predicting clinical outcome of epidermal growth factor receptor-targeted therapy in metastatic colorectal cancer. J Natl Cancer Inst 101: 1308-1324, 2009.

11. Alarmo EL, Rauta J, Kauraniemi P, Karhu R, Kuukasjärvi T and Kallioniemi A: Bone morphogenetic protein 7 is widely overexpressed in primary breast cancer. Genes Chromosomes Cancer 45: 411-419, 2006.

12. Miyazaki H, Watabe T, Kitamura T and Miyazono K: BMP signals inhibit proliferation and in vivo tumor growth of androgen-insensitive prostate carcinoma cells. Oncogene 23: 9326-9335, 2004.

13. Beck SE, Jung BH, Del Rosario E, Gomez J and Carethers JM: BMP-induced growth suppression in colon cancer cells is mediated by p21WAF1 stabilization and modulated by RAS/ERK. Cell Signal 19: 1465-1472, 2007.

14. Aoki M, Ishigami S, Uenosono Y, Arigami T, Uchikado Y, Kita Y, Kurahara H, Matsumoto M, Ueno S and Natsugoe S: Expression of BMP-7 in human gastric cancer and its clinical significance. Br J Cancer 104: 714-718, 2011.

15. Fleming ID, Cooper J, Henson DE, Hutter VPR, Kennedy BJ, Murphy GP, O'Sullivan B, Sobin LH, Yarbro JW, et al (eds): AJCC cancer staging manual. 5th edition. Lippincott-Raven, Philadelphia, PA, 1997.

16. Rodriguez-Martinez A, Alarmo EL, Saarinen L, Ketolainen J, Nousiainen K, Hautaniemi S and Kallioniemi A: Analysis of BMP4 and BMP7 signaling in breast cancer cells unveils time-dependent transcription patterns and highlights a common synexpression group of genes. BMC Med Genomics 4: 80, 2011.

17. Huh JW, Park YA, Jung EJ, Lee KY, Kwon JE and Sohn SK: Complete remission of unresectable colon cancer after preoperative chemotherapy selected by adenosine triphosphate-based chemotherapy response assay. J Korean Med Sci 23: 916-919, 2008.

18. Sorbye SW, Kilvaer T, Valkov A, Donnem T, Smeland E, Al-Shibli K, Bremnes RM and Busund LT: Prognostic Impact of Lymphocytes in Soft Tissue Sarcomas. PLoS One 6: e14611, 2011.

19. Motoyama K, Tanaka F, Kosaka Y, Mimori K, Uetake H, Inoue H, Sugihara K and Mori M: Clinical significance of BMP7 in human colorectal cancer. Ann Surg Oncol 15: 1530-1537, 2008.

20. Megumi K, Ishigami S, Uchikado Y, Kita Y, Okumura H, Matsumoto M, Uenosono Y, Arigami T, Kijima Y, Kitazono M, et al: Clinicopathological significance of BMP7 expression in esophageal squamous cell carcinoma. Ann Surg Oncol 19: 2066-2071,2012. 